\title{
Academic Research In Technology Innovation Management and Related Thematic Areas in Brazil
}

\author{
Adalberto Mantovani M. de Azevedo', Marcela de Oliveira Mazzoni², Marco Antonio Silveira ${ }^{3}$
}

\begin{abstract}
This paper presents a profile of a Brazilian academic research group in areas related to the management of technology innovation. Keywords searches have been chosen to generate a database composed of information about research groups, projects that are funded by Brazilian Federal Government and scientific journals. Data analysis allowed the following conclusions: I. Most research groups have been established in the 2000 s, when innovation Policies have been settled in Brazil; 2. Most of the research is located in regions which have better science and technology infrastructure; 3 . There is low interaction between researchers and public/private companies; 4. Federal Agencies tend to support projects related to innovation policy instruments (technology parks, local production systems, technology transfer centers in universities and research institutes).
\end{abstract}

Keywords: innovation management; research groups; research mapping.

'Public Policy Professor, Federal University of ABC (UFABC).Alameda Gaspar Nogueira, I62,AP 84-B, Bairro Jardim, Santo André-SP, Brasil. 09090-010. Phone: 55 (19) 9860-884I.E-mail: adalberto.azevedo@ufabc.edu.br

${ }^{2}$ Doctoral Candidate, Department of Science and Technology Policy, State University of Campinas (UNICAMP).Av. Carlos de Araújo Gobbi, 444, AP 6I-D,Vila São Bento, Campinas-SP, Brasil. I3034-670. Phone: 55 (19) 3308-7I I 7. E-mail: marcelamazzoni@gmail.com

${ }^{3}$ Researcher, Group for Support of Innovation and Learning in Organizations (G.A.I.A), Center for Information Technology Renato Archer (CTI-MCTI). Rod. Dom Pedro I km I43, Campinas-SP, Brazil, I3069-90I.Phone: 55 (I9) 3746-6083. E-mail: marco.silveira@cti.gov.br 


\section{Introduction}

The present paper is the result of a research group annual planning activities in the area of technology innovation management and related topics.Among other activities, the group's planning sought to identify and map institutions, researchers, events, publications and other elements related to the thematic areas targeted by the research group activities. This paper presents the mapped information based on the thematic areas detailed in Chart I.

The variety of thematic areas shown in Chart I is coherent with the multidisciplinary nature of technology innovation management studies, which requires a combination of a variety of competences and capabilities. Nevertheless, the majority of papers in the area are based on a one-dimensional approach, which does not considers internal organizational processes such as knowledge management and organizational learning, that are imperatives to the success of innovative efforts:

"The management of innovation is inherently interdisciplinary and multifunctional, but most management texts tend to emphasize a single dimension, such as the management of research and development, production and operations management, marketing management, product development and organizational development [...] The latest management research and the experience of leading practitioners confirm that significant dimensions in the management of innovation are not satisfactorily addressed by management teaching or texts [...] The management of organizational innovation has shifted from an emphasis on "change management" of structure and culture, to the design and improvement of internal processes, such as knowledge management, and external linkages and networks."(Tidd, Bessant and Pavitt, 2005: xiii-xiv)
The focus on three thematic areas shown in Chart I comes from the characteristics of the activities developed by the research group. Although being an academic research group, activities are guided by research-action methods (Franco, 2005), here understood as a research that intends to transform reality with the active participation of researchers, as well as through interaction with research subjects. Thus, to ensure successful interventions at the research groups in public and private organizations, it is considered essential to integrate multidisciplinary knowledge areas related to innovation management and learning processes. The mix of knowledge areas allows instrumental application of knowledge generated by the group, which gives meaning to research and encourages engagement of external organizations.

To collect information used in the mapping of thematic areas, explorations were performed using keywords searches terms, which are listed in Chart I. The following databases have been explored:A. Directory of Research Groups of the National Council of Scientific and Technological Development (CNPq) website (CNPq, 20I Ia); B. Projects funded by the National Fund for Scientific and Technological Development (FNDCT) through the government agencies such as $\mathrm{CNPq}$ and Financing Agency for Studies and Projects (Finep) between 1997 and 2010 (SIGCTI, 20II); C. Journals and events listed in the database of Federal Government Coordination for the Improvement of Higher Education Personnel (CAPES) (CAPES, 20II).

The present paper is organized in six sections, besides this introduction. The second section discusses the emergence of technology innovation management as a new field of scientific knowledge, and describes the evolution of this field of

\begin{tabular}{|l|l|}
\hline Thematic areas & Detailing of thematic areas (keywords) \\
\hline $\begin{array}{l}\text { Innovation } \\
\text { management for } \\
\text { organizational } \\
\text { ecosystems } \\
\text { sustainability. }\end{array}$ & $\begin{array}{l}\text { Tools for knowledge dissemination and knowledge flow management in organizational } \\
\text { ecosystems (distance learning, social networking, etc.). Cooperative organizational systems } \\
\text { (networks, triple helices, innovation systems, etc.). Relational capital. University- industry } \\
\text { cooperation. Technology transfer. Environmental, economic and social sustainability of organi- } \\
\text { zations (triple bottom-line approach). }\end{array}$ \\
\hline $\begin{array}{l}\text { Innovation and } \\
\text { knowledge ma- } \\
\text { nagement }\end{array}$ & $\begin{array}{l}\text { Knowledge and intellectual capital. Intellectual capital management. Organizational knowl- } \\
\text { edge management. Knowledge dissemination and corporative portals on web. Balanced } \\
\text { Scorecard (BSC). Core competencies based strategies. Management of research, develop- } \\
\text { ment and innovation. Management information systems. Chaos theory and complexity in } \\
\text { organizations. Information technologies for business management. }\end{array}$ \\
\hline $\begin{array}{l}\text { Management of } \\
\text { organizational } \\
\text { learning. }\end{array}$ & $\begin{array}{l}\text { Organizational learning (andragogy, heutagogy, e-learning). Human factor in organizations. } \\
\text { Integration JTPD (Job-Training-Personal Development). Corporate education and corpo- } \\
\text { rate university. Management skills and KSA model (Knowledge, Skills and Attitudes). Human } \\
\text { Capital Management. }\end{array}$ \\
\hline
\end{tabular}

Chart I.Thematic areas related to technology innovation management. Source: Author

ISSN: 07 I8-2724. (http://www.jotmi.org)

Journal of Technology Management \& Innovation (c) Universidad Alberto Hurtado, Facultad de Economía y Negocios. 
study in the World and in Brazil. The third section presents the mapping of CNPq's Research Groups, characterizing I I 9 research groups in technology innovation management. The fourth section presents some projects funded by FNDCT, characterizing 102 projects related to thematic areas. The fifth section characterizes I4 Brazilian journals dedicated to the field of innovation management and related topics. The sixth section presents the conclusions of the paper.

\section{Technological innovation management and related areas: a new scientific field}

The application of methodologies for technology innovation management is a crucial factor for organizations where technology change meets customers' demands by developing proprietary technologies (Quadros, 2008). Technology change, however, is a process fraught with uncertainties and risks, which creates the need to develop and implement very specific management methods:

"However, the management of innovation is inherently difficult and risky: most new technologies fail to be translated into products and services, and most new products and services are not commercial successes. In short, innovation can enhance competitiveness, but it requires a different set of management knowledge and skills from those of everyday business administration." (Tidd, Bessant and Pavitt, 2005: xiii). To address the complexity of innovation management, an increasing amount of academic papers have been written in the "innovation studies" field (Fagerberg and Verspagen, 2009). According to the authors, this is a new field of scientific knowledge, still undefined as a formal scientific discipline due to the lack of elements that characterize scientific disciplines understood as "traditional", such as graduate and post-graduate teaching, consolidated curricula and textbooks.

Publications about innovation studies started to become popular in the 1960s, starting with works developed by the United States Air Force Research and Development Corporation (RAND, created after World War II) (Fagerberg and Verspagen, 2009). One of the RAND's researchers, Richard Nelson, published in 1959 the paper "The simple economics of basic scientific research". In 1962, Richard Nelson organized the book "The Rate and Direction of Inventive Activity", considered by Fagerberg and Verspagen (2009) the starting point for the field of innovation studies. The book includes seminal papers written by some of the most cited authors in the field, such as Jacob Schmookler ("Changes in Industry and in the State of Knowledge as Determinants of Industrial Invention"), John L. Enos ("Invention and Innovation in the Petroleum Refining Industry") and Kenneth Arrow ("Economic Welfare and the Allocation of Resources for Invention").
Outside USA, Fagerberg e Verspagen (2009) highlight the foundation in 1965 of the Science Policy Research Unity (SPRU), a British teaching and research institution that has settled an interdisciplinary masters and doctorate courses in the field of innovation management. SPRU has also established in 1972 the journal Research Policy, the first peerreviewed journal specialized in technology innovation management and related thematic areas.

In Brazil, systematic efforts have been made to establish studies on science, technology and innovation policies, most of them led by CNPq in the 1980s, when the agency created the "Center for Studies in Science and Technology Policy". From this initiative, CNPq sought to institutionalize similar centers at universities and research institutions (Fernandes, 1996). The program was discontinued in the early 1990s, but some of the centers installed in the 1980s progressed and developed post-graduate programs in the field, for instance, the masters and doctoral courses offered by the Department of Science and Technology Policy from the State University of Campinas (DPCT/Unicamp).

Academic work focused on technology innovation management only became academically relevant in Brazil during the 1990s (Quadros, 2008), focusing on methods to improve the management of government funding of Research and Development (R\&D). However, these studies considered the management of R\&D as a separate function from others "traditional" management sectors (finance, production, marketing, etc.). Only in the 2000 s the management of innovation began to be studied as integrated to all organizational processes and dependent of learning processes which involve internal and external actors. The shift to this more complex and systemic view was influenced by the diffusion, in the 1990s, of studies from abroad explaining innovative processes by means of systemic approaches.

The emergence the technology innovation management as a new field of scientific knowledge in Brazil also motivated the mapping that is presented in the paper. The following sections will be an overview of Brazilian's research in the field, mapping some characteristics of main three actors in the research community: research groups, research projects and scientific journals.

\section{Research groups in technology innovation manage- ment and related thematic areas}

The information presented in this section was gathered at the CNPq's Directory of Research Groups (DGP), by performing searches about all research groups registered in the DGP system. DGP started its databank about research groups in 1992, through collaboration among research institutions managers, leaders of research groups and research-

ISSN: 07 I8-2724. (http://www.jotmi.org)

Journal of Technology Management \& Innovation (c) Universidad Alberto Hurtado, Facultad de Economía y Negocios. 
ers, that provided information about research activities to DGP database system (CNPq, 20I Ic).

DGP is a source of data that has been widely used in the mapping of specific research areas due to its functionality to identifying and characterizing academic research groups using keywords searches. Examples of works on DGP's database include the mapping of epidemiology studies by Guimarães, Lourenço and Cosac (200I); mapping of researches in human aging (Prado e Sayd, 2004); profile of research groups about food and nutrition security (Prado et al, 20l0); and Rapini's (2007) paper of interactions between research groups and private companies.
The study presented in this paper has identified 119 research groups, using searchers engine in the DGP database, with the keywords listed on Chart I. Chart 2 shows that the number of research groups presents a higher rate of growth in the 2000 s, when $78.2 \%$ of the currently existent research groups have been settled. Moreover, the growth rate of research groups was more intense than the growth rate of all groups registered in the DGP database since 1992. The total of research groups registered in the DGP increased from 4,402 in 1993 to 22,797 in 2008, representing a growth rate of $417.9 \%$ (CNPq, 20l l b). Research groups on technology innovation management increased from nine groups in 1993 to 91 groups in 2008, representing a growth rate of $911 \%$.

\begin{tabular}{|l|l|l|}
\hline Period & $\mathrm{N}^{\circ}$ of research groups created & $\%$ of the total number of research groups (20I I) \\
\hline 1983 a 1990 & 2 & $1.7 \%$ \\
\hline 1990 a 1995 & 12 & $10.1 \%$ \\
\hline 1995 a 2000 & $\mathrm{II}$ & $9.2 \%$ \\
\hline 2001 a 2005 & 36 & $30.3 \%$ \\
\hline 2005 a 2011 & 57 & $47.9 \%$ \\
\hline 1983 a 2011 & 119 & $100 \%$ \\
\hline
\end{tabular}

Chart 2. Evolution of technology innovation management research groups and percentage of the total. Source: CNPq Research Groups Directory (DGP)

\begin{tabular}{|c|c|c|c|}
\hline Main knowledge area & Knowledge areas & \begin{tabular}{|l|} 
Research \\
groups
\end{tabular} & \\
\hline & & Number & $\%$ \\
\hline Hard and Earth Sciences & Computer Science & 5 & 4.20 \\
\hline \multirow[t]{4}{*}{ Human Sciences } & Political Science & 1 & 0.84 \\
\hline & Sociology & 2 & 1.68 \\
\hline & Psychology & 3 & 2.52 \\
\hline & Education & 4 & 3.36 \\
\hline \multirow[t]{6}{*}{ Social Sciences } & Communication & I & 0.84 \\
\hline & Urban and regional planning & I & 0.84 \\
\hline & Law & 3 & 2.52 \\
\hline & Economics & 8 & 6.72 \\
\hline & Information science & 12 & 10.08 \\
\hline & Administration & 61 & 51.26 \\
\hline \multirow[t]{2}{*}{ Engineering } & Metallurgical and Materials Engineering & 1 & 0.84 \\
\hline & Production Engineering & 14 & 11.76 \\
\hline Technologies & Social and educational technologies & 3 & 2.52 \\
\hline Total & - & 119 & 100 \\
\hline
\end{tabular}

Chart 3. Number of research groups on innovation management and related areas classified by knowledge areas, $20 \mathrm{II}$. Source: CNPq Research Groups Directory (DGP)

ISSN: 07 I8-2724. (http://www.jotmi.org)

Journal of Technology Management \& Innovation (C) Universidad Alberto Hurtado, Facultad de Economía y Negocios. 
These numbers indicate that research in innovation management has been gaining ground recently, especially after 2000 . The creation of research groups on innovation management in Brazil in early 2000s followed the establishment of S\&T policies to stimulate innovation. The policies aimed to aligning innovation and industrial policies with developmental policy goals (Pacheco, 2003). In fact, some innovation policies had been carried out before 1999, focusing on strengthening science and technology activities. Nevertheless, excepting the creation of Oil and Gas Sectoral Research Fund in 1997, policies focused in innovation only began in the 2000 s. Between 2000 and 200I, a set of S\&T Regulations created twelve Sectoral Research Funds, the Innovation Law (2004) and incentives to stimulate innovation in companies ( $\mathrm{Pa}-$ checo, 2003; Melo, 2010).

The characterization of the prevalent knowledge areas in the research groups analyzed shows a strong concentration in administrative sciences departments, representing more than half of the research groups knowledge areas in 201 I (6I research groups). It is also remarkable the participation of production engineering departments, representing $11.76 \%$ of total research groups (14 research groups). Information science departments have a participation of $10.08 \%$ (12 research groups). There is also a presence of research groups in "hard" sciences departments, related to applied sciences.

Classification by knowledge areas does not reveal specifically which area related to innovation management is focused on the research groups' activities. A more detailed investigation classifying research groups according to the thematic areas is described on Chart I and is organized in: I. Innovation management for organizational ecosystems sustainability; 2. Innovation and knowledge management; 3. Organizational learning management. The classification was based on research groups activities description, available in the
DGP database. This information allowed classifying groups according to their focus (Chart 4). The first thematic area - innovation management for sustainability of organizational ecosystems - includes the majority of research groups, since it encompasses a broad set of themes, such as innovation clusters, technology parks, public policies for S,T\&l, technology transfer, among others. The two remaining thematic areas (knowledge management and organizational learning) are more specific and for this reason present a smaller number of research groups.

The institutional affiliation of research groups shows the prevalence of groups based in public universities. From 119 mapped research groups, 86 were affiliated to public universities, 25 were affiliated to private universities and eight were affiliated to research institutes (Graphic I). The three institutions with larger number of research groups on technology innovation management were public institutions: São Paulo University (USP) (nine research groups out of II9); Federal Technology University of Paraná (UTFPR) (eight research groups); and Brasília University (UNB) (five research groups). State University of Campinas (UNICAMP), Federal University of São Carlos (UFSCAR), Federal University of Paraná (UFPR), Federal University of Rio de Janeiro (UFRJ) and Federal University of Rio Grande do Sul (UFRGS) had each one four research groups on technology innovation management based in academic departments.

The regional distribution of research groups shows a higher concentration in the Southeast Region (4I.2\% out of the total groups), followed by the South Region (32.8\%) and Northeast Region (I5.1\%) (Graphic 2). This distribution is consistent with the overall distribution of research groups in the DGP: in 2008, the Southeast Region concentrated $48.8 \%$ of the groups, the South Region $23.2 \%$, the Northeast Region 16.9\%, the Central-West Region 6.4\% and the North Region 4.7\% (CNPq, 20II). States with a higher num-

\begin{tabular}{|l|l|l|l|}
\hline Thematic areas & $\begin{array}{l}\text { Number of } \\
\text { research } \\
\text { groups }\end{array}$ & Knowledge areas (number of research groups) & $\begin{array}{l}\text { Types of institutions (num- } \\
\text { ber of research groups) }\end{array}$ \\
\hline $\begin{array}{l}\text { I.Innovation management for organ- } \\
\text { izational ecosystems sustainability }\end{array}$ & 69 & $\begin{array}{l}\text { Administrative sciences (37), production engineering (II), } \\
\text { economics (8), information science (3), Law (3), computer } \\
\text { science (I), education (I), sociology (I), political science (I), } \\
\text { urban and regional planning (I), metallurgical and materials } \\
\text { engineering (I), educational technologies and social services } \\
\text { (I). }\end{array}$ & $\begin{array}{l}\text { Public universities (5I), } \\
\text { private universities (II), } \\
\text { research institutes (7) }\end{array}$ \\
\hline $\begin{array}{l}\text { 2.Innovation and knowledge man- } \\
\text { agement }\end{array}$ & 25 & $\begin{array}{l}\text { information science (9), administration (8), computer science } \\
(2), \text { production engineering (2), information technology and } \\
\text { communication (2), communication (I), psychology (I) }\end{array}$ & $\begin{array}{l}\text { Public universities (I7), } \\
\text { private universities (7), } \\
\text { research institutes (I) }\end{array}$ \\
\hline $\begin{array}{l}\text { 3.Organizational learning manage- } \\
\text { ment }\end{array}$ & 25 & $\begin{array}{l}\text { Administration (I6), education (3), computer science (2), } \\
\text { psychology (2), production engineering (I), sociology (I) }\end{array}$ & $\begin{array}{l}\text { Public Universities (I8), } \\
\text { private universities (6), } \\
\text { research institutes (I) }\end{array}$ \\
\hline
\end{tabular}

Chart 4. Thematic areas focused by research groups on technology innovation management, $20 \mathrm{II}$. Source: CNPq Research Groups Directory (DGP)

ISSN: 07 I8-2724. (http://www.jotmi.org)

Journal of Technology Management \& Innovation (c) Universidad Alberto Hurtado, Facultad de Economía y Negocios. 
ber of research groups on technology innovation management were located in São Paulo State (32 research groups), Paraná State (18 research groups) and Rio Grande do Sul State (12 research groups). This distribution, which reflects the regional concentration of human and material resources of S\&T in Brazil, is a problem addressed by recent policies aiming to decentralize S\&T research groups, funding and infrastructure. On the other side, the increase of funding for innovation in less developed regions makes even more necessary the presence of research groups specialized in the management of technological innovation that could supply consultancy services for innovation projects of public and private organizations (e.g. planning and assessment).

29 (24.37\%) out of I I 9 research groups developed external relationships with private companies, public institutions or nongovernmental organizations (Chart 5). Most of research groups were located in São Paulo State's institutions ( 10 research groups with external relationships), followed by Minas Gerais and Paraná States, each one with four external relationships. The small number of research groups' relationships with non-academic institutions is a negative characteristic of Brazilian research groups on technology innovation management, even more considering the potential benefits that could be provided for public and private organizations innovation initiatives.

\section{Research projects on technology innovation man- agement funded by Brazililian Federal Government}

The search of research projects funded by Federal agencies has been made on the National Fund for Scientific and Technological Development (FNDCT) database (SIGCTI, 20I I). The searches were based on keywords listed in Chart I, and

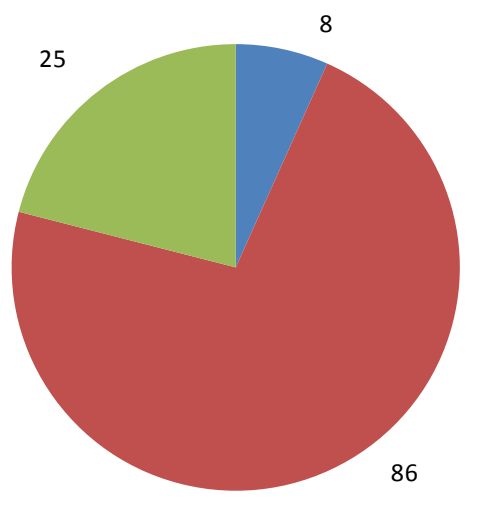

- Research Institutes

- Public Universities

- Private Universities Graphic I. Number of research groups on technology innovation management by types of research Institution, 201 I.
Source: CNPq Research Groups Directory (DGP)

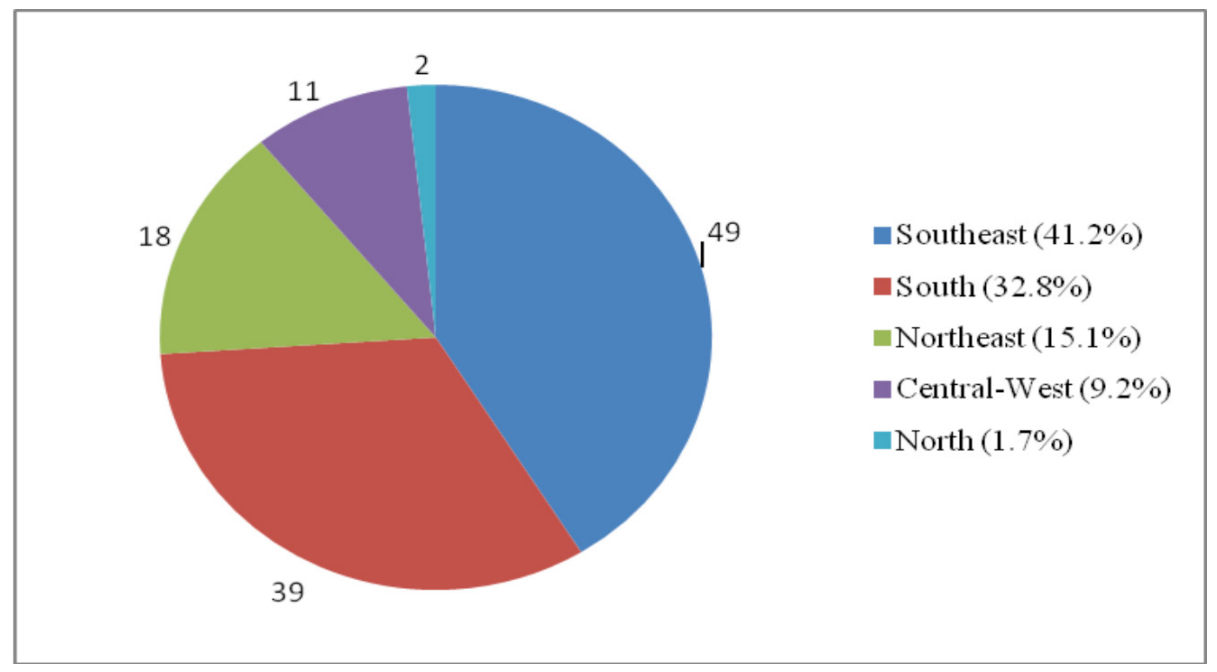

Graphic 2. Number of research groups on technology innovation management, Brazilian Regions, and percentage of the total number of research groups, 20I I. Source: CNPq Research Groups Directory (DGP)

ISSN: 07 I8-2724. (http://www.jotmi.org)

Journal of Technology Management \& Innovation (c) Universidad Alberto Hurtado, Facultad de Economía y Negocios. 
resulted in 102 research projects about technology innovation management between 1999 and 2010 funded by $\mathrm{CNPq}$ or Finep.

The majority of the 102 research projects have been scheduled to begin their activities in 2006. It is difficult to explain the variation observed on the numbers shown in Graphic 3. This variation is probably related to funding opportunities, such as public calls for research proposals.

The total amount of resources for the 102 projects reached US\$ 43 million, and the average value of each project was US $\$ 420$ thousand. The number of projects according to ranges of funding resources is shown in Graphic 4.

According to SIGCTI (20II), 32 projects were directed to support events on innovation management (workshops, seminars, conferences, etc), absorbing $0.83 \%$ of total resources. The remaining 70 research projects shared $99.17 \%$ of the total funding resources. Finep supported 97 projects corresponding to $99.22 \%$ of total, and only five projects have been funded through CNPq ( $0.78 \%$ of total).
Chart $4 \mathrm{~b}$ shows the distribution of projects and funds according to the State where the leading Institution is installed. Financial resources distribution reflects regional inequalities on S\&T infrastructure, also dependent on local governments initiatives on the creation and coordination of innovation policies supported by S\&T States' Secretariats.

Institutions that executed projects have been classified in five categories (Chart 5). Chart 5 points out that the majority of projects have been executed by universities and research institutes. The variety of institutions financed shows the diversity of projects purposes, e.g., the promotion of events and the implementation of local innovation policies.

Examining in detail, many projects are not academic research projects, consisting on the implementation of public policies aimed at the consolidation of regional innovation systems, such as technology parks installation and incentives to university-industry relationships. Chart 6 classifies projects according to public policies programs defined on MCTI 2007-20IO Plan of Action on Science, Technology and Innovation (PACTI).

\begin{tabular}{|l|l|}
\hline Characteristic & Description (number of research groups) \\
\hline Region & Southeast (16), South (8), other regions(5) \\
\hline Type of research Institution & Public Universities (22), private universities (5), research institutes (2) \\
\hline $\begin{array}{l}\text { Type of external organiza- } \\
\text { tion }\end{array}$ & Private companies (17), private companies and public companies (7), public companies (3), NGOs (2) \\
\hline Thematic areas & $\begin{array}{l}\text { Innovation management for organizational ecosystem sustainability (I8), Innovation and knowledge manage- } \\
\text { ment (6), Organizational learning management (5) }\end{array}$ \\
\hline
\end{tabular}

Chart 5. Characteristics of research groups on technology innovation management with external relationships, $201 \mathrm{I}$. Source: CNPq Research Groups Directory (DGP)

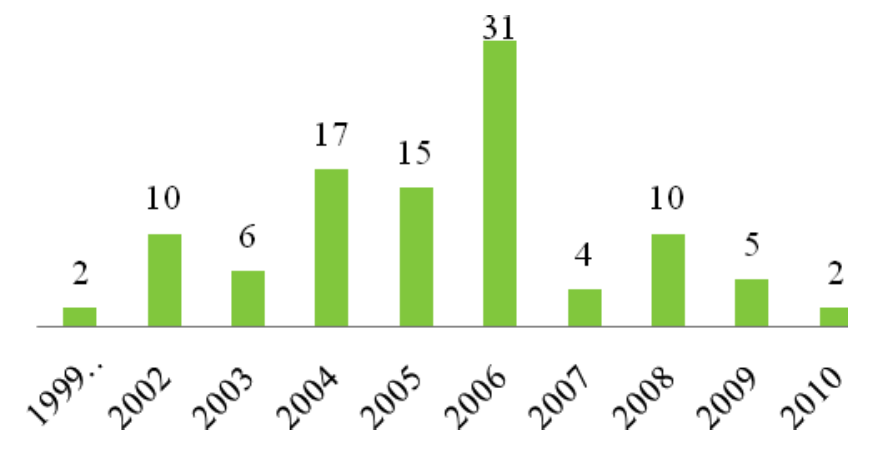

Graphic 3. Technology innovation management projects starting year, 1999-20I0 Source: SIGCTI (20II)

ISSN: 07 I8-2724. (http://www.jotmi.org)

Journal of Technology Management \& Innovation (c) Universidad Alberto Hurtado, Facultad de Economía y Negocios. 


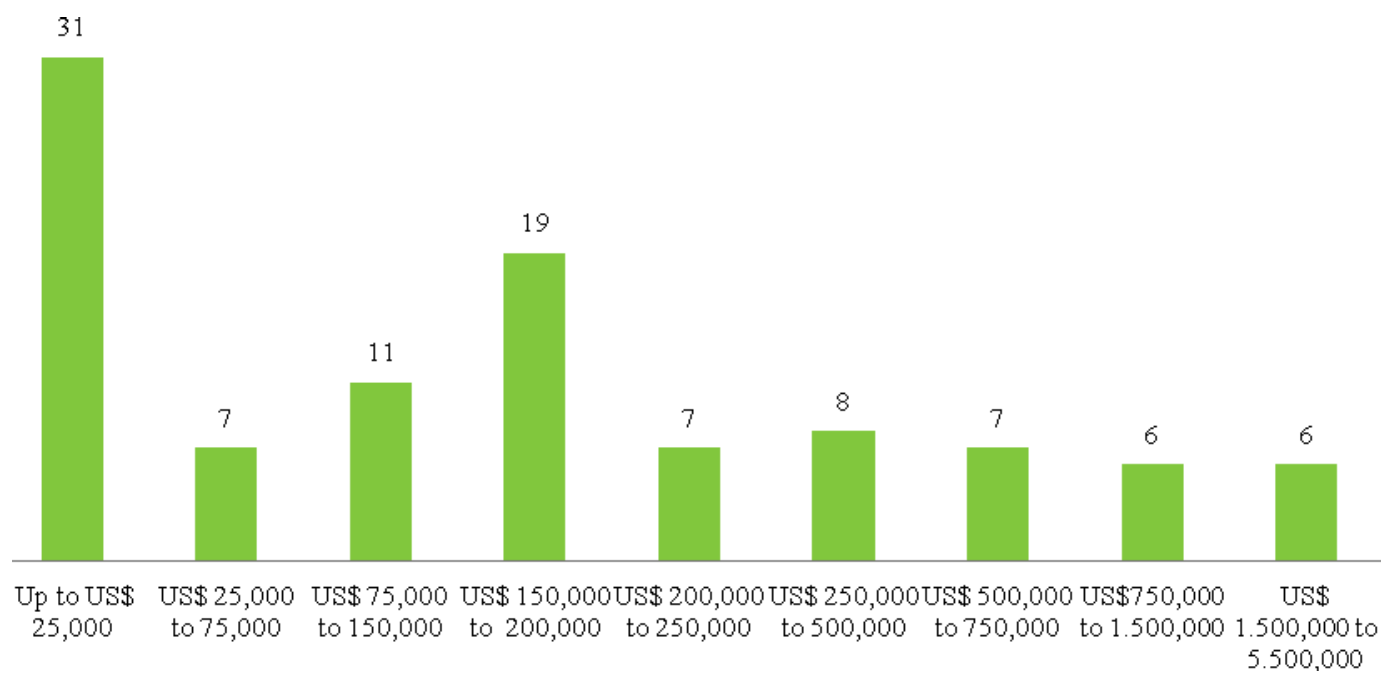

Graphic 4. Distribution of research projects on technology innovation management by range of funding resources. Source: SIGCTI (20II)

\begin{tabular}{|c|c|c|c|c|}
\hline State & Total funds by State (US $\$$ ) & $\%$ of total funds & Number of projects & Average value of projects (US\$) \\
\hline Alagoas & 130,900 & 0.30 & $\mathrm{I}$ & 130,900 \\
\hline Amazonas & 105,829 & 0.25 & 2 & 52,914 \\
\hline Bahia & $7,604,640$ & 17.72 & 3 & $2,534,880$ \\
\hline Ceará & 15,000 & 0.03 & 1 & 15,000 \\
\hline $\begin{array}{l}\text { Distrito } \\
\text { Federal }\end{array}$ & $5,231,381$ & 12.19 & 12 & 435,948 \\
\hline $\begin{array}{l}\text { Espírito } \\
\text { Santo }\end{array}$ & 112.163 & 0.26 & 1 & 112,163 \\
\hline Goiás & $1,213,351$ & 2.83 & 2 & 606,675 \\
\hline Minas Gerais & $5,458,474$ & 12.72 & 8 & 682,309 \\
\hline $\begin{array}{l}\text { Mato Grosso } \\
\text { do Sul }\end{array}$ & 160,216 & 0.37 & 1 & 160,216 \\
\hline Pará & $1,828,237$ & 4.26 & 2 & 914,118 \\
\hline Pernambuco & $5,|35,07|$ & 11.97 & 4 & $1,283,767$ \\
\hline Paraná & $1,119,212$ & 2.61 & 8 & $139,90 \mid$ \\
\hline $\begin{array}{l}\text { Rio de } \\
\text { Janeiro }\end{array}$ & $2,207,003$ & 5.14 & 14 & 157,643 \\
\hline $\begin{array}{l}\text { Rio Grande } \\
\text { do Norte }\end{array}$ & 76,335 & 0.18 & 2 & 38,167 \\
\hline $\begin{array}{l}\text { Rio Grande } \\
\text { do Sul }\end{array}$ & $1,802,633$ & 4.20 & 11 & 163,875 \\
\hline $\begin{array}{l}\text { Santa Cata- } \\
\text { rina }\end{array}$ & $1,865,549$ & 4.35 & 9 & 207,283 \\
\hline São Paulo & $8,849,223$ & 20.62 & 21 & 421,391 \\
\hline Total & $42,915,217$ & 100.00 & 102 & 420,737 \\
\hline
\end{tabular}

Chart 4b. Federally funded projects on technology innovation management, distribution by Brazil's States, 20 I I. Source: SIGCTI (20II)

ISSN: 07 I8-2724. (http://www.jotmi.org)

Journal of Technology Management \& Innovation (c) Universidad Alberto Hurtado, Facultad de Economía y Negocios. 
Projects on PACTI Program "Institutional expansion and consolidation of the national system of S,T\&l", aimed at the expansion of the institutional structure of Brazil's S,T\&I system (MCT, 2010) had most of their resources (US\$ 16 million) applied in four projects for the installation of technology parks and business incubators. Projects related to "Brazilian Technology System (SIBRATEC)" Program, aimed at stimulating technology transfer from public research institutes to private companies, were focused on 18 projects (that absorbed US\$ 6.2 million) for the creation or consolidation of Technology Innovation Centers (NITs) for technology transfer support.

The Five projects with the highest values objectives also indicate the tendency to invest Federal resources in public innovation policies. Four projects (with an average value of US\$ 3,9 million) have been funded through the Public Call "Invitation Letter to States- MCT/Finep/Transversal ActionsStructural projects for S,T\&I- 12/2007", directed to States Secretariats of S,T\&I. The project with the higher funding (US $\$ 5,5$ million) has been executed by Bahia State Foundation for Research Support (Fapesba), through the Public Call "MCT/FINEP - PAPPE (Program for Research Support on Private Companies) Subvention - 02/2006", and aimed the creation of institutions specialized on the support of private companies innovative activities.

By crossing project coordinators names with research groups coordinators names it has been possible to check the participation of academic research groups on the projects funded through Finep and CNPq. From 119 research groups, only seven coordinators obtained federal budget resources for projects execution (Chart 7).

\section{Scientific journals on technology innovation man- agement}

The journals listed on this section have been gathered from the Federal Government's Coordination for the Improvement of Higher Education Personnel (CAPES) database, available in CAPEs' website (CAPES, 20II). Graphic points that I4 Brazilian Journals specialized on technology innovation management were identified.

The oldest journal found is the "Science Journal", edited by the Brazilian Society for Scientific Progress. However, this periodical publication can be categorized in dissemination of scientific knowledge magazine, i.e., it does not publish peer reviewed papers. In general, most of the scientific journal identified has been launched after 2000, the same period when the creation of research groups on technology innovation management started to be significant.

The knowledge fields covered by the journals are similar to the areas focused by most of the research groups, as shown in the Graphic 6, concentrated on Administrative sciences studies. It is worth to mention the significant participation of the interdisciplinary area, coherently with the interdisciplinary characteristic of innovation studies.

The majority of technology innovation management journals are based in public universities, as shown in Graphic 7. This distribution corresponds to research groups institutional affiliations.

Finally, the distribution of scientific journals on technology innovation management among Brazilian States confirms the concentration of journals in regions with more developed $S, T \& I$ infrastructure. Only two journals were affiliated to North and Northeast regions Institutions.

\begin{tabular}{|l|l|l|l|l|}
\hline Type of institution & $\begin{array}{l}\text { Number of } \\
\text { projects }\end{array}$ & $\begin{array}{l}\text { Total funds by type of } \\
\text { institution (US\$) }\end{array}$ & $\begin{array}{l}\text { \% of total } \\
\text { funds }\end{array}$ & Projects objectives (number of projects) \\
\hline Private associations & 8 & $\mathrm{I}, 214,595$ & 2.84 & Events (5), Research Projects (3) \\
\hline Private companies & 2 & 265,319 & 0.62 & Research Projects (2) \\
\hline Technical schools & $\mathrm{I}$ & 4,978 & $0.0 \mathrm{I}$ & Events (I) \\
\hline $\begin{array}{l}\text { States foundations for re- } \\
\text { search support }\end{array}$ & 3 & $7,54 \mathrm{I}, 44 \mathrm{I}$ & 17.58 & Research Projects (3) \\
\hline Government & 2 & $199, \mathrm{II}$ & 0.46 & Events (I), Research Projects (I) \\
\hline Business incubators & 6 & $\mathrm{I}, 314,152$ & 3.06 & Research Projects (6) \\
\hline Research institutes & 24 & $15,929,115$ & 37.23 & Events (2), Research Projects (22) \\
\hline NGOs & 18 & $\mathrm{I}, 443,576$ & 3.47 & Events (II), Research Projects (7) \\
\hline Universities & 38 & $\mathrm{I} 4,898,70 \mathrm{I}$ & 34.73 & Events (9), Research Projects (29) \\
\hline
\end{tabular}

Chart 5. Federally funded projects on technology innovation management, distribution by executing Institution, I999-20I0. Source: SIGCTI (20II)

ISSN: 07I 8-2724. (http://www.jotmi.org)

Journal of Technology Management \& Innovation (c) Universidad Alberto Hurtado, Facultad de Economía y Negocios. 


\begin{tabular}{|l|l|l|l|}
\hline PACTI programs & Number of projects & Projects funding by program (US\$) & \% of total funds \\
\hline $\begin{array}{l}\text { Institutional expansion and consolidation of the national system of } \\
\text { S,T\&I }\end{array}$ & 6 & 18,29 million & 42.44 \\
\hline Brazilian Technology System (SIBRATEC) & 31 & 9,75 million & 22.91 \\
\hline $\begin{array}{l}\text { Financial support to R,D\&I and academic researchers projects on } \\
\text { private companies }\end{array}$ & 4 & 6,26 million & 15.70 \\
\hline National Program of Business Incubators and Technology Parks & 13 & 4,41 million & 10.25 \\
\hline Support for infrastructure on research institutions & 5 & 1,21 million & 2.82 \\
\hline Formation and qualification of Human Resources for S,T\&I & 6 & 800,000 & 1.86 \\
\hline $\begin{array}{l}\text { Support for events and projects related to scientific and technological } \\
\text { dissemination of knowledge, and education }\end{array}$ & 31 & 540,000 & 1.28 \\
\hline Software and services to strengthening program & 2 & 502,000 & 1.21 \\
\hline National innovation initiative & 1 & 407,000 & 0.95 \\
\hline Support for university-industry cooperation & 1 & 175,000 & 0.41 \\
\hline Support for scientific, technological and innovative development & 2 & 75,000 & 0.17 \\
\hline
\end{tabular}

Chart 6. Federally funded projects on technology innovation management distribution by PACTI programs. Source: SIGCTI (20I I)

\begin{tabular}{|l|l|}
\hline Research group features & Description (number of research groups) \\
\hline Location (Brazilian States) & Paraná (3), São Paulo (2), Santa Catarina (I), Bahia (I) \\
\hline Type of Institution & Public universities (6), Research institutes (I) \\
\hline Total amount of investment in projects & US\$ 4,6 million \\
\hline Average budget for projects & US\$ 650,000 \\
\hline Executing Institutions & Universities (5) e Research institutes (I) \\
\hline Projects with non-academic organizations participation & 3 \\
\hline
\end{tabular}

Chart 7. Federally funded projects on technology innovation management coordinated by research groups leaders, $201 \mathrm{I}$. Source: CNPq Research Groups Directory (DGP) and SIGCTI (20II)

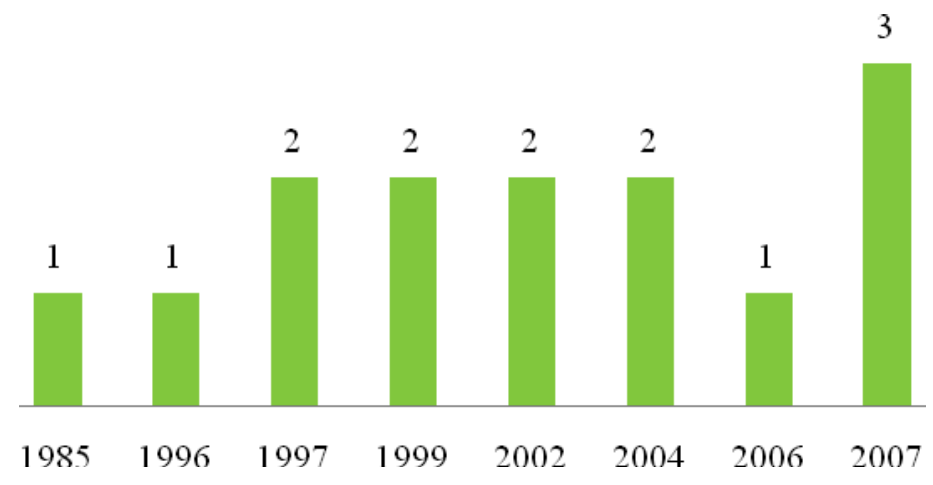

Graphic 5. Number of scientific journals on technology innovation management launched by year, Brazil, 1985-2007. Source: CAPES (20II)

ISSN: 07 I 8-2724. (http://www.jotmi.org)

Journal of Technology Management \& Innovation (c) Universidad Alberto Hurtado, Facultad de Economía y Negocios. 


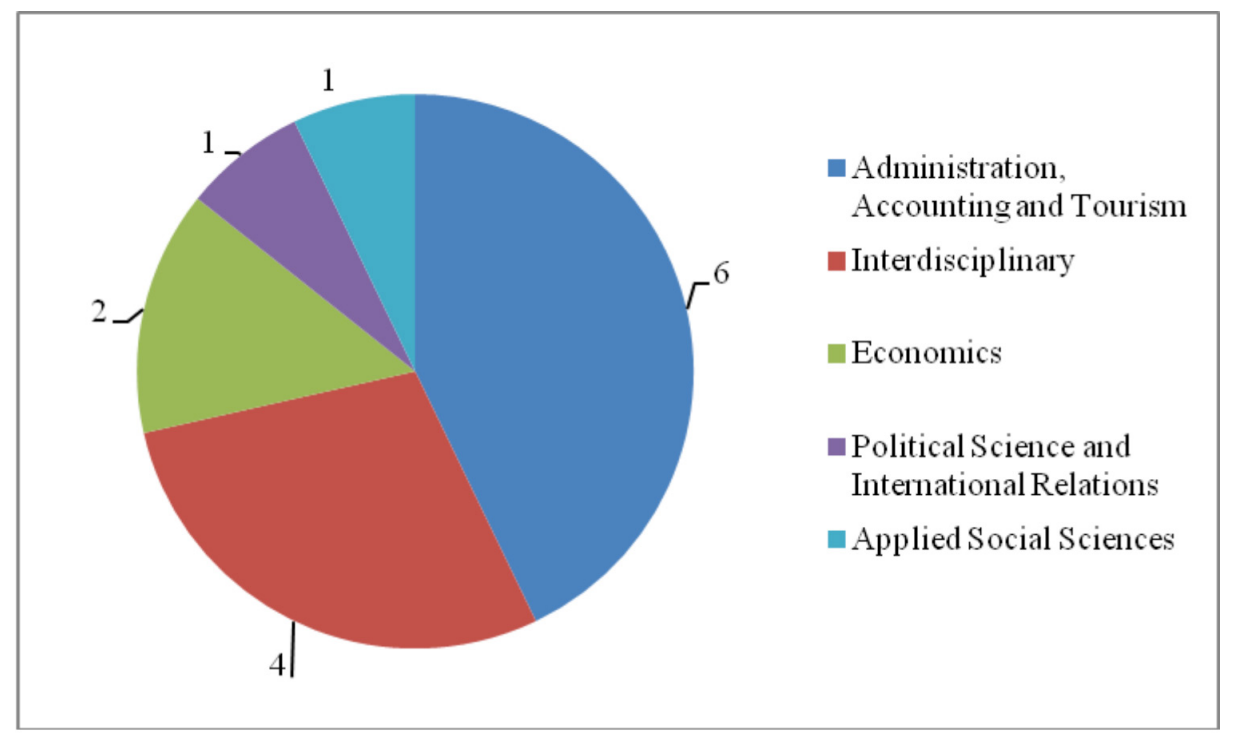

Graphic 6. Knowledge areas of scientific journals on technology innovation management, Brazil, 20I I Source: CAPES (20II)

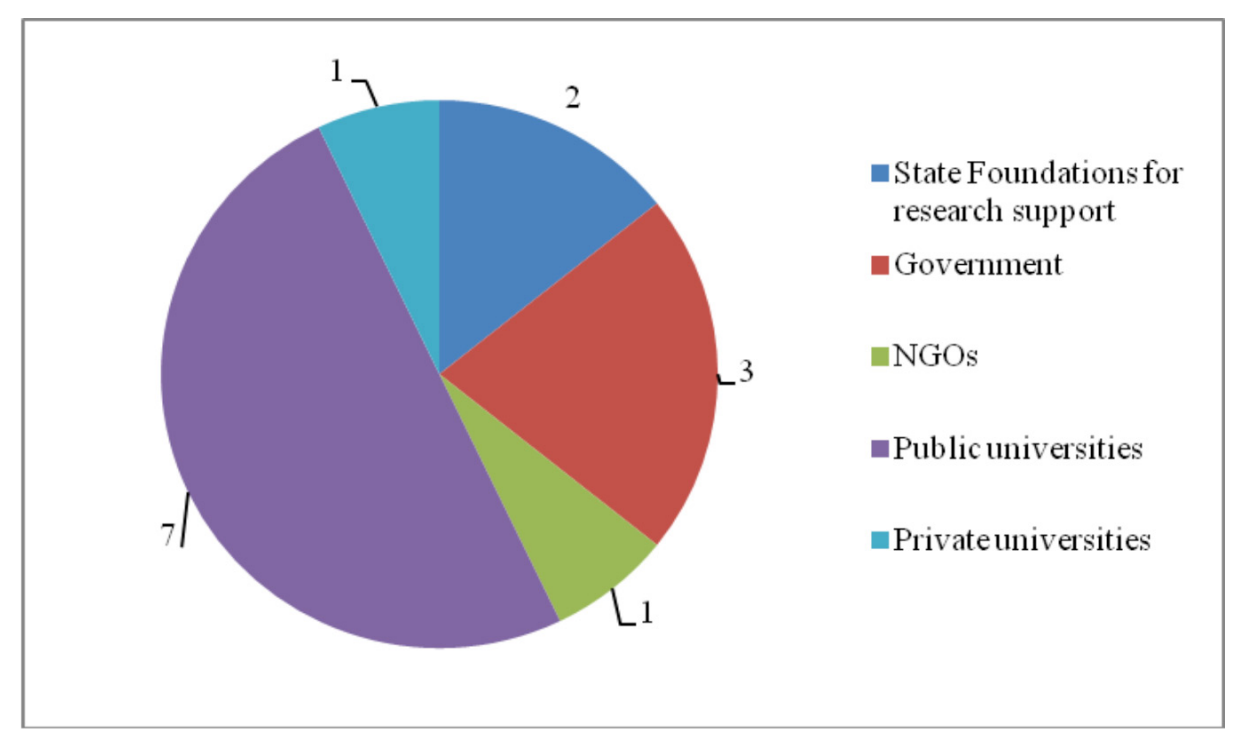

Graphic 7. Institutional affiliation of scientific journals on technology innovation management, Brazil, 20 I I Source: CAPES (20 I I)

\begin{tabular}{|l|l|}
\hline Brazil's States & Number of journals \\
\hline Distrito Federal & 3 \\
\hline Maranhão & $\mathrm{I}$ \\
\hline Minas Gerais & $\mathrm{I}$ \\
\hline Paraná & 2 \\
\hline Pernambuco & $\mathrm{I}$ \\
\hline São Paulo & 6 \\
\hline
\end{tabular}

Chart 7b. Scientific journals on technology innovation management location by Brazil's States, 20II Source: CAPES (20II) 


\section{Conclusions}

Technology management methodologies and techniques are essential to manage innovation in public and private organizations. Academic research and consultancy in technology innovation management have potential to be a valuable external resource that can be used by organizations for the improvement of management methodologies and human resources training.

Technology innovation management is an interdisciplinary field of knowledge, which brings together different knowledge specialties necessary to the management of organizational change. As a new knowledge field, the technology innovation management field has not consolidated disciplinary elements, such as academic curricula and basic textbooks. Nevertheless, the interdisciplinary character of the technology innovation management field turns knowledge in this field a powerful tool for applied research on public and private organizations problems.

The focus on knowledge application is one of the key features for planning activities that generated the present paper. Based on the idea that there can be no innovation without knowledge acquisition through learning processes, data collection focused on three areas of interest: I.Technology innovation management for organizational ecosystems sustainability; 2 . Innovation and knowledge management; 3. Management of organizational learning.

The planning of the research group activities included the mapping of Brazilian academic research on the three thematic areas listed above. This mapping generated the opportunity for the elaboration of the present paper, which systematically presents information about research groups, projects funded by Brazil's Federal Government and indexed journals.

In this paper, there have been identified I 9 research groups, the majority created after 2000, together with the launching of public policies with the aim of intensify innovative activities in universities, research institutes and private companies. The more common knowledge field of the research groups is administrative sciences, but the areas of production engineering and information science have also an important presence on the research groups surveyed. The thematic area more focused by research groups is technology innovation management for organizational ecosystems sustainability. Research groups are predominantly based in public universities on the Southeast Region, showing an undesirable regional concentration of competences on this knowledge field. Finally, a very small proportion of research groups have any relationship with public or private external organizations. This indicates an under-exploitation of the knowledge generated by research groups, which could have an important role on improving innovation management in public and private organizations.

Searches of projects funded by Brazilian federal agencies resulted on a database with 102 projects on the technology innovation management field. The regional distribution of funding is less concentrated than the distribution of research groups, as a result of MCTI's policies aiming for the regional deconcentration of the S,T\&l funding. Regional distribution of Federal funding also reflects the execution of public policies for innovation funded by MCTI's resources. In fact, a good proportion of the projects supported aimed at policy objectives such as technology parks creation, incentives to local production systems and creation of technology innovation centers in public universities and research centers dedicated to technology transfer activities (a mandatory requirement for public institutions in Brazil since 2004). Institutional distribution of projects reflects the variety of project goals, including private associations, private companies, technical schools, States foundations for research support, government institutions, business incubators, research institutes, universities and NGOs. Finally, it is noticeable the low presence of research groups leaders on federally funded projects.

Survey in Brazilian indexed journals on technology innovation management shows a regional and knowledge field distribution similar to research groups. Most of journals are supported by Southeast region institutions, mainly on the administrative sciences knowledge field.

Summarizing, the mapping presented in this paper shows the following features of academic research in Brazil on technology innovation management: I.The development of research groups and funding of federally funded projects occurs simultaneously to the settlement of innovation public policies; 2. Research groups, project funding, and scientific journal are concentrated on regions with better S,T\&I infrastructure; 3 . Most of the research groups, funded projects and journals focused on the administrative sciences field; 4 . Research groups have weak relationships with external organizations; 5. A significant amount of MCTI funding was applied to support regional public policies of S,T\&l. 
References

ANDRADE, E. I. G. et al (2007). Pesquisa e produção científica em economia da saúde no Brasil. Revista de Administração Pública, v.4I, n.2, 2 I I-235.

CONSELHO NACIONAL DE DESENVOLVIMENTO CIENTÍFICO E TECNOLÓGICO (CNPq) (20lla). Diretório dos Grupos de Pesquisa do Brasil- Busca textual de grupos certificados na base atual do Diretório. Web: http:// dgp.cnpq.br/buscaoperacional/. [07/02/20II]

(20l lb). Séries Históricas- Diretório dos Grupos de Pesquisa no Brasil. Web: http://dgp.cnpq.br/censos/series_historicas/index_basicas.htm. [08/02/20II]

(20I Ic). Manual do Pesquisador- Diretório dos Grupos de Pesquisa no Brasil. Web: http://dgp.cnpq.br/censos/series_ historicas/index_basicas.htm. [08/02/20II]

COORDENAÇÃO DE APERFEIÇOAMENTO DE PESSOAL DE NÍVEL SUPERIOR (CAPES).(20II). Lista Completa de Periódicos (página da internet). Web: http://qualis. capes.gov.br/webqualis/ConsultaListaCompletaPeriodicos. faces. [30/06/20I I]

FARGENBERG, B., Verspagen, B. (2009). Innovation studies: the emerging structure of a new scientific field. Research Policy, v.38, n.2, 21 8-233.

FERNANDES, A.M. (1996). Estudos de ciência e tecnologia no Brasil: um balanço crítico. Cadernos de Ciência \& Tecnologia, v. I3, n. I, 43-56.

FRANCO, M. A. S. (2005). Pedagogia da Pesquisa-Ação. Educação e Pesquisa, v.3 I , n.3, 483-502.

FREITAS, C. M. et al. (2009). Quem é quem na saúde ambiental brasileira? Identificação e caracterização de grupos de pesquisas e organizações da sociedade civil. Ciência e Saúde Coletiva, v. |4, n.6, 207|-2082.

GUIMARÃES, R.; Lourenço, R., Cosac, S. (200I). A pesquisa em epidemiologia no Brasil. Revista de Saúde Pública, v.35, n. $4,321-340$.

MINISTÉRIO DA CIÊNCIA E TECNOLOGIA (MCT). (2010). Fundos Setoriais: Relatório de Gestão 2007-2009. MCT. Web: http://www.mct.gov.br/upd_blob/02 I I/21 I 799. pdf. [2I/06/20l I]

MELO, L.C.P. (20I0). Uma nova geração de políticas de ciência, tecnologia e inovação. Parcerias Estratégicas, v.I5, n.3I, 175- 180.
PRADO, S. D.; Sayd, J. D. (2004). A pesquisa sobre envelhecimento humano no Brasil: grupos e linhas de pesquisa. Ciência e Saúde Coletiva, v.9, n. I, 57-67.

PRADO, S. D. et al. (2010). A pesquisa sobre segurança alimentar e nutricional no Brasil de 2000 a 2005: tendências e desafios. Ciência e Saúde Coletiva, v. I5, n. I, 7-I8.

QUADROS, R. (2008). Aprendendo a inovar: padrões de gestão da inovação tecnológica em empresas brasileiras. VIII Conferência Nacional da ANPEI, 30 p.

RAPINI, M. S. (2007). Interação universidade-empresa no Brasil: evidências do Diretório dos Grupos de Pesquisa do CNPq. Estudos Econômicos, v.37, n. I , 2 I I-233.

RAPINI, M. S. (2007). O Diretório dos Grupos de Pesquisa do CNPq e a interação universidade-empresa no Brasil: uma proposta metodológica de investigação. Revista de Economia Contemporânea, v. I I, n. I, 99-II7.

SISTEMA INTEGRADO DE GESTÃO DE CIÊNCIA, TECNOLOGIA E INOVAÇÃO (SIGCTI) (MCT). (20II). Web: http://sigcti.mct.gov.br/fundos/rel/ctl/ctl.php?act=demanda. buscar_form. [I2/05/20II]

TIDD, J.; Bessant, J.; Pavitt, K. (2005). Managing innovation: integrating technological, market and organizational change. Wiley, London.

ZAWISLAK, P.A. (1994). Gestão da inovação tecnológica e competitividade industrial: uma proposta para o caso brasileiro. Organizações \& Sociedade, v. 2, n. 3, 35-66. 


\section{APPENDIX NOTES}

Fagerberg and Verspagen (2009) consider as part of a specific scientific field the investigations around particular cognitive problems, with common focuses and knowledge shared by members of the field.

According to Fagerberg and Verspagen (2009), before the 1960s only Joseph Schumpeter's works could be considered innovation studies. Marx theories on technological development are also considered important, although Marx's focus was not the study of technical change.

The classification accuracy is limited by the information presented in the DGP database. Besides, many research groups investigate two or three thematic areas considered in this research. More accurate results could be obtained from the examination of the scientific production of the groups (papers, thesis, projects, extension work, etc.), which is beyond the scope of this paper, and a suggestion for further investigation.

For example, Law 10.197/200 I determined that at least 30\% of research funding should be invested in institutions in the North, Northeast and Central-West regions of Brazil.

Established in 2007, PACTI objective is the long-term coordination of S,T\&I activities developed by Brazilian Institutions. PACTI is divided in four priority areas: I. Expansion and consolidation of the national system of S,T\&l; 2. Promotion of technology innovation on private companies; 3 . Research, development and innovation on strategic areas; 4 . S,T\&l for social development (MCT, 20I0).

NITs are technology transfer offices located on public universities and research institutes. Their creation on public institutions has become mandatory in 2004 through Brazil's Innovation Law (Law nr. 10973).

Five journals founded also can be classified as scientific and technological magazines: "Fapesp Research", "ComCiência”, "Knowledege and Innovation" and "Innovation Magazine (FAPEMA)". 